\title{
Identification of Nutrition, Phytochemicals and Antioxidants Taro (Colocasia sp)
}

\author{
Arlin, B. D. ${ }^{1}$, Fadjar, K. H. ${ }^{2}$, Nunuk, H. ${ }^{3}$ \\ \{fadjar.kurnia@unitomo.ac.id ${ }^{2}$ \} \\ ${ }^{1,2,3}$ Universitas Dr. Soetomo, Indonesia
}

\begin{abstract}
The purpose of this study is to ensure that the leaves and fronds of taro leaves can be used as alternative food ingredients and to find out which varieties can be consumed because Indonesia has several types of taro. This research method is experimental using standard analysis methods. Based on the results of identification, it was shown that the leaves and taro fronds could potentially be used as food ingredients and beneficial for health because they also contain phenols, flavonoids, and antioxidants.
\end{abstract}

Keywords: Leaves; Midrib; Taro; Phenol; Flavonoids and Antioxidants

\section{Introduction}

Indonesia is one of the countries that has a variety of local food that has the potential as an alternative food source and needs to be developed to support food security, such as maize, beans, and tubers [1]. One tuber that has a contribution in maintaining food security in the country and also has the potential as an export item that can generate profits is taro, so the demand for taro tubers is also increasing [2]. The increasing demand for taro tubers, the more leaves and midribs produced, which until now have not been utilized.

Whereas according to Wei et al [3] taro is a food crop in the form of chronic herbs which are included in the tribe of taro (Araceae) and the whole part of taro plants can be used as food, medicine, and feed ingredients. Mohan and Pandey [4] added that taro leaves are thought to function as a new wound dressing or as an alternative medicine for wounds. Taro plants are also thought to contain flavonoids and saponins [5] as cosmetic formulas and are also suitable as a degraded plastic material which can be degraded [6]. Before utilizing leaves and taro fronds as food, it must be known in advance the nutritional content, vitamins, and minerals because there is no information related to this matter. Based on previous research, measurement of phenol and flavonoid content was only carried out qualitatively. Therefore it is necessary to do a quantitative analysis of the nutrient content, phenols, flavonoids, and antioxidant leaves and taro fronds.

\section{Method}

Samples were leaves (D) and taro fronds (L) taken at the East Java Agricultural Technology Study Centre, Indonesia, each of which were 5, namely Xanthosoma sagitifolium (D1 \& L1), Xanthosoma sagitifolium Black (D2 \& L2), Colocasia gigantean (D3 \& L3) ), C. esculenta L. schooott (D4 \& L4) and black lump (D5 \& L5) so that there are 10 samples. Preparation of the sample was carried out by thin slicing with a thickness of about $0.5 \mathrm{~cm}$ and dried with Freeze dry temperature of $-400 \mathrm{C}$, after drying, smoothed with a blender and sifted to obtain leaf powder and taro fronds. This method is done because the sample secretes mucus 
when macerated in a fresh state so it is difficult to filter. Furthermore, this powder is analyzed by proximate (protein, fat, water, ash, and carbohydrates), crude fibre, vitamins (A, B1, and C) and minerals ( $\mathrm{Fe}, \mathrm{Ca}$ and $\mathrm{P})([7] ;[8])$ and the acute toxicity study [9].

Samples for phytochemical tests, antioxidant activity and toxicity were taken by means of powder samples soaked with distilled water (1:3) while stirring for 1 hour and left for 24 hours, centrifuged (1500 rpm temperature 40 OC) and the filtrate was taken. Phenol levels were measured by the method of Lopez et al. [10] flavonoids [7] antioxidant activity using the DPPH method [11].

\section{Result and Discussion}

\subsection{Nutrition}

The leaf nutrition and midrib of each taro can be seen in Table 1 where the protein content of taro leaves is higher when compared to the levels of taro frond protein.

Table 1. Average leaf nutrient levels and taro fronds (\%) in 100 grams of sample

\begin{tabular}{lccccccc}
\hline No & $\begin{array}{c}\text { Sample } \\
\text { Code }\end{array}$ & $\begin{array}{c}\text { Protein } \\
\text { Level }(\%)\end{array}$ & $\begin{array}{c}\text { Fat Level } \\
(\%)\end{array}$ & $\begin{array}{c}\text { Moisture } \\
\text { Content }(\%)\end{array}$ & $\begin{array}{c}\text { Ash Level } \\
(\%)\end{array}$ & $\begin{array}{c}\text { Kh Level } \\
(\%)\end{array}$ & $\begin{array}{c}\text { Crude Fibre } \\
\text { Content }(\%)\end{array}$ \\
\hline 1. & D1 & 2,29 & 0,53 & 90,97 & 1,65 & 4,56 & 2,17 \\
2. & D2 & 1,50 & 0,61 & 87,24 & 1,70 & 8,95 & 2,85 \\
3. & D3 & 4,11 & 0,61 & 82,34 & 1,99 & 10,95 & 3,63 \\
4. & D4 & 2,31 & 0,38 & 79,33 & 1,83 & 16,15 & 2,37 \\
5. & D5 & 2,91 & 1,16 & 83,56 & 2,00 & 10,37 & 2,93 \\
6. & P1 & 0,30 & 0,23 & 95,24 & 1,02 & 3,21 & 1,21 \\
7. & P2 & 0,20 & 0,46 & 93,41 & 1,14 & 4,79 & 1,90 \\
8. & P3 & 0,20 & 0,13 & 92,36 & 1,03 & 6,28 & 1,44 \\
9. & P4 & 0,30 & 0,15 & 92,93 & 1,07 & 5,55 & 1,73 \\
10 & P5 & 0,20 & 0,31 & 93,97 & 0,88 & 4,64 & 1,41 \\
11. & control & 2,20 & 0,40 & 73,00 & 1,00 & 22,20 & 0,80 \\
\hline
\end{tabular}

Remarks: D1 = leaf kimpul, D2 = leaf kimpul hitam, D3 = leaf lompong, D4 = bentul, D5 = black leaf, P1

= midrib midrib, $\mathrm{P} 2=$ midrib midrib, $\mathrm{P} 3=$ midrib midrib, $\mathrm{P} 4=$ bent midrib, $\mathrm{P} 5=$ black clumps and

Control $=$ taro tubers

The protein content of taro leaves is higher when compared to a protein content of spinach leaves, but lower when compared with protein levels of kale leaves $(3.4 \%)$, katuk leaves $(6.4 \%)$ and cassava leaves $(6.2 \%)$. The fat content of leaves and taro fronds is not much different from commonly consumed vegetables such as spinach, mustard greens, kale, katuk leaves, cassava leaves etc. which are around $0.1 \%$ to $1 \%$. The water content of leaves and taro fronds is not much different from commonly consumed vegetables such as spinach, mustard greens, kale, katuk leaves, cassava leaves etc. which are around $80 \%$ to $90 \%$. The leaf ash content and taro fronds are not much different from commonly consumed vegetables such as spinach, mustard greens, kale, katuk leaves, cassava leaves, etc. which are around $1.02 \%$ to $2.15 \%$. The carbohydrate content of leaves and taro fronds has lower carbohydrate levels compared to the carbohydrate content of taro tubers (22.2\%). In accordance with the opinion of Liu et al [12] that taro tubers are one of the important foods because of their starch content. The level of the crude fibre of taro leaves is not much different from commonly consumed vegetables such as spinach, mustard greens, kale, katuk leaves, cassava leaves etc. which is around $2 \%$. However, taro fronds have lower crude fibre levels compared to the vegetables mentioned above [13]. 


\subsection{Vitamins and Minerals}

Vitamins and minerals of each sample can be seen in table 2

Table 2. Average levels of vitamin and mineral leaves and taro fronds

\begin{tabular}{lccccccc}
\hline \multirow{2}{*}{ No } & Sample & \multicolumn{3}{c}{ Vitamin } & \multicolumn{3}{c}{ Mineral } \\
\cline { 3 - 8 } & Code & $\begin{array}{c}\mathrm{A} \\
\mu \mathrm{g} / \mathrm{g}\end{array}$ & $\begin{array}{c}\mathrm{B} 1 \\
(\mathrm{mg} / 100 \mathrm{~g})\end{array}$ & $\begin{array}{c}\mathrm{C} \\
(\mathrm{mg} / 100 \mathrm{~g})\end{array}$ & $\begin{array}{c}\mathrm{Fe} \\
(\mathrm{ppm})\end{array}$ & $\begin{array}{c}\mathrm{Ca} \\
(\mathrm{ppm})\end{array}$ & $\begin{array}{c}\mathrm{P} \\
(\mathrm{ppm})\end{array}$ \\
\hline 1. & $\mathrm{D} 1$ & 62,47 & 0,81 & 11,76 & 18,15 & 997,40 & 1087,31 \\
2. & $\mathrm{D} 2$ & 116,29 & 1,02 & 30,80 & 35,24 & 1049,74 & 965,48 \\
3. & $\mathrm{D} 3$ & 96,99 & 0,07 & 11,76 & 36,32 & 1104,80 & 2082,00 \\
4. & $\mathrm{D} 4$ & 62,78 & 0,13 & 33,11 & 35,63 & 1016,42 & 2303,98 \\
5. & $\mathrm{D} 5$ & 118,05 & 0,06 & 7,07 & 18,07 & 992,73 & 1362,05 \\
6. & $\mathrm{P} 1$ & 0,76 & 0,09 & 4,74 & 22,78 & 492,14 & 43,44 \\
7. & $\mathrm{P} 2$ & 1,13 & 0,07 & 16,57 & 21,74 & 504,77 & 251,89 \\
8. & $\mathrm{P} 3$ & 0,69 & 1,01 & 2,36 & 15,63 & 439,10 & 360,71 \\
9. & $\mathrm{P} 4$ & 0,32 & 0,14 & 2,37 & 18,01 & 433,24 & 817,92 \\
10 & P5 & 0,79 & 0,06 & 18,98 & 11,32 & 379,46 & 306,15 \\
11. & control & 3,00 & 0,05 & 2,00 & 0,12 & 3,4 & 6,2 \\
\hline
\end{tabular}

Remarks: D1 = leaf kimpul, D2 = leaf kimpul hitam, D3 = leaf lompong, D4 = bentul, D5 = black leaf, $\mathrm{P} 1=$ midrib midrib, $\mathrm{P} 2=$ midrib midrib, $\mathrm{P} 3=$ midrib midrib, $\mathrm{P} 4=$ bent midrib, $\mathrm{P} 5=$ black clumps and Control $=$ taro tubers.

The content of vitamins $\mathrm{A}$ and $\mathrm{C}, \mathrm{Fe}, \mathrm{Ca}$ and $\mathrm{P}$ minerals in leaves and taro midribs is higher compared to spinach leaves, kale, katuk and cassava except vitamin B1 is not much different from those vegetables. Food that contains calcium and phosphorus is needed by our bodies [14].

\subsection{Phenol, Flavonoids and Antioxidant Activities}

Total phenol levels, flavonoids and antioxidant activity of leaves and taro leaves can be seen in Table 3 below

Table 3. Average levels of total phenol, flavonoids and antioxidant activity of leaves and taro

\begin{tabular}{lcccc}
\hline \multicolumn{5}{c}{ fronds } \\
No & $\begin{array}{c}\text { Sample } \\
\text { Code }\end{array}$ & $\begin{array}{c}\text { Total Phenol Level } \\
\text { (mg GAE / g extract) }\end{array}$ & $\begin{array}{c}\text { Total Flavonoid Levels } \\
\text { (mg QE / g extract) }\end{array}$ & $\begin{array}{c}\text { IC50 value } \\
\text { (ppm) }\end{array}$ \\
\hline 1. & D1 & 45,01 & 19,28 & 70,91 \\
2. & D2 & 67,51 & 23,40 & 61.42 \\
3. & D3 & 47,23 & 17,29 & 72,71 \\
4. & D4 & 50,07 & 19,01 & 74,18 \\
5. & D5 & 63,35 & 19,42 & 60,27 \\
6. & P1 & 50.61 & 18,73 & 71,36 \\
7. & P2 & 90,53 & 41,06 & 62,27 \\
8. & P3 & 54,07 & 18,37 & 71,86 \\
9. & P4 & 49,37 & 16,39 & 75,64 \\
10 & P5 & 91,28 & 37,25 & 61,12 \\
\hline
\end{tabular}

Remarks: D1 = leaf kimpul, D2 = leaf kimpul hitam, D3 = leaf lompong, D4 = bentul, D5 = black leaf, $\mathrm{P} 1=$ midrib midrib, $\mathrm{P} 2=$ midrib midrib, $\mathrm{P} 3=$ midrib midrib, $\mathrm{P} 4=$ bent midrib, $\mathrm{P} 5=$ black clumps and Control $=$ taro tubers 
The total levels of leaf flavonoids and taro midribs can be seen in Table 5. The lowest total flavonoid levels were $16.39 \mathrm{mg} \mathrm{QE} / \mathrm{g}$ found in taro midribs, while the highest total flavonoid levels were $41.06 \mathrm{mg} \mathrm{QE} / \mathrm{g}$ extract is found in the black imprint midrib. Furthermore, Yilma et al. [15] stated that flavonoids are a group of phenolic compounds that are widely available in nature such as vegetables, fruits, seeds, and others.

The total phenol content of leaves and taro fronds ranged from $45.01 \mathrm{mg} \mathrm{GAE} / \mathrm{g}$ extract to $91.28 \mathrm{mg} \mathrm{GAE} / \mathrm{g}$ extract, meaning that the results of this analysis showed that leaves and taro fronds contained phenol so that it was potentially as one of the functional ingredients or can be used further as a food ingredient or as a material that is beneficial for health.

Taro leaves and taro fronds have high antioxidant activity because they have an IC50 value of less than $200 \mu \mathrm{g} / \mathrm{ml}$. This is in accordance with the opinion of Molyneux [13] which states that the test material is said to have high antioxidant activity if it has an IC50 value of less than $200 \mu \mathrm{g} / \mathrm{ml}$.

\subsection{Acute toxicity extract of leaf water and taro fronds}

Giving extract of leaf water and taro fronds at various doses do not cause mice to die after a 168-hour maintenance period, as shown in Table 4.

Table 4. Number of mice deaths by giving leaf extracts and taro leaves for 168 hours

\begin{tabular}{ccccccccccc}
\hline Dose & \multicolumn{8}{c}{ The number of deaths of mice 0-168 hours } \\
\cline { 2 - 12 } g/kg BB & D1 & D2 & D3 & D4 & D5 & P1 & P2 & P3 & P4 & P5 \\
\hline 0 & 0 & 0 & 0 & 0 & 0 & 0 & 0 & 0 & 0 & 0 \\
10,50 & 0 & 0 & 0 & 0 & 0 & 0 & 0 & 0 & 0 & 0 \\
15,75 & 0 & 0 & 0 & 0 & 0 & 0 & 0 & 0 & 0 & 0 \\
21,00 & 0 & 0 & 0 & 0 & 0 & 0 & 0 & 0 & 0 & 0 \\
\hline
\end{tabular}

The highest dose given to experimental animals is called LD50 [16]. This study shows that giving the highest dose does not cause mice to die.

\section{Conclusion}

The leaves and taro midribs that have not been used so far have the potential to be used as food because they contain sufficiently complete nutrients and even have the potential to be functional because they contain phenols, flavonoids, have high antioxidant activity and do not cause death in mice.

\section{References}

[1] P. V. Sulistyowati, N. Kendarini, and R. Respatijarti, "Observasi keberadaan tanaman talas-talasan genus Colocasia dan Xanthosoma di Kec. Kedungkandang Kota Malang dan Kec. Ampelgading Kab. Malang," J. Produksi Tanam., vol. 2, no. 2, 2014.

[2] S. Koswara, "Teknologi Pengolahan Umbi-Umbian Bagian 7: Pengolahan Umbi Garut," Trop. Plant Curric. Proj. Bogor, Indones. IPB, 2010.

[3] L. S. Wei, W. Wee, J. Y. F. Siong, and D. F. Syamsumir, "Characterization of antimicrobial, antioxidant, anticancer property and chemical composition of Michelia champaca seed and flower extracts," Stamford J. Pharm. Sci., vol. 4, no. 1, pp. 19-24, 2011.

[4] D. R. S. M. MOHAN, D. R. B. PANDEY, and B. M. MAHAVIDYALAYA, "PROJECT 


\section{REPORT OF MINOR RESEARCH PROJECT."}

[5] P. R. Pereira, A. C. N. T. F. Corrêa, M. A. Vericimo, and V. M. F. Paschoalin, "Tarin, a Potential Immunomodulator and COX -Inhibitor Lectin Found in Taro (Colocasia esculenta)," Compr. Rev. Food Sci. Food Saf., vol. 17, no. 4, pp. 878-891, 2018.

[6] M. Setyowati, "Karakteristik umbi plasma nutfah tanaman talas (Colocasia esculenta)," 2018.

[7] T. V Krishnapriya and A. Suganthi, "Biochemical and phytochemical analysis of Colocasia esculenta (L.) Schott tubers," Int. J. Res. Pharm. Pharm. Sci., vol. 2, no. 3, pp. 21-25, 2017.

[8] A. T. Valson et al., "Profile of incident chronic kidney disease related-mineral bone disorders in chronic kidney disease Stage 4 and 5: A hospital based cross-sectional survey," Indian J. Nephrol., vol. 24, no. 2, p. 97, 2014.

[9] T. A. Loomis and A. W. Hayes, Loomis's essentials of toxicology. Elsevier, 1996.

[10] C. V. Vázquez et al., "Total phenolic compounds in milk from different species. Design of an extraction technique for quantification using the Folin-Ciocalteu method," Food Chem., vol. 176, pp. 480-486, 2015.

[11] F. Della Pelle et al., "Antioxidant capacity index based on gold nanoparticles formation. Application to extra virgin olive oil samples," Food Chem., vol. 178, pp. 70-75, 2015.

[12] F. Zeng, H. Liu, and G. Liu, "Physicochemical properties of starch extracted from Colocasia esculenta (L.) Schott (Bun -long taro) grown in Hunan, China," Starch Stärke, vol. 66, no. 1-2, pp. 142-148, 2014.

[13] P. Molyneux, "The Use of the Stable Free Radical Diphenylpicryl-hydrazyl (DPPH) for Estimating Antioxidant Activity," Songklanakarin J. Sci. Technol., 2004.

[14] J. Li, J. Ma, S. Chen, J. He, and Y. Huang, "Characterization of calcium alginate/deacetylated konjac glucomannan blend films prepared by $\mathrm{Ca} 2+$ crosslinking and deacetylation," Food Hydrocoll., vol. 82, pp. 363-369, 2018.

[15] A. N. Yilma, S. R. Singh, L. Morici, and V. A. Dennis, "Flavonoid naringenin: a potential immunomodulator for Chlamydia trachomatis inflammation," Mediators Inflamm., vol. 2013, 2013.

[16] I. I. Chukwuonye et al., "Prevalence of overweight and obesity in adult Nigerians-a systematic review," Diabetes, Metab. Syndr. Obes. targets Ther., vol. 6, p. 43, 2013. 